\title{
A small place, by Jamaica Kincaid: envisioning literary tourism in Antigua
}

\section{Rita Baleiro \& Sílvia Quinteiro}

To cite this article: Rita Baleiro \& Sílvia Quinteiro (2019) A small place, by Jamaica Kincaid: envisioning literary tourism in Antigua, Journal of Tourism and Cultural Change, 17:6, 676-688, DOI: $10.1080 / 14766825.2018 .1529772$

To link to this article: https://doi.org/10.1080/14766825.2018.1529772

\section{Published online: 07 Oct 2018.}

Submit your article to this journal $\pi$

Џll Article views: 1080

Q View related articles $\sqsubset$

View Crossmark data $\nearrow$ 


\title{
A small place, by Jamaica Kincaid: envisioning literary tourism in Antigua
}

\author{
Rita Baleiro (D) and Sílvia Quinteiro \\ Languages Department, School of Management, Hospitality and Tourism, University of the Algarve, Faro, \\ Portugal
}

\begin{abstract}
This work departs from a reading of the novelistic essay $A$ small place (1988), by Jamaica Kincaid, to analyse the representation of the tourism industry and of tourists in Antigua (the author's birthplace). From there, we present Kincaid's text as 'tourist literature' (Hendrix, 2014), also aiming to contribute to the examination of tourism-centred literary texts. Within the context of literature and tourism studies as well as comparative studies, this paper examines Kincaid's literary text in order to consider the promotion of literary tourism in Antigua. This example is then considered in light of recent contributions from literary tourism, space production, community-based tourism, mass tourism as well as responsible and sustainable tourism. Literary heritage as a resource for the tourism industry could bring tourists and locals closer and conspire to break down barriers between the largely dark-skinned hosts and the white tourists in Antigua.
\end{abstract}

\section{ARTICLE HISTORY}

Received 16 October 2017

Accepted 24 September 2018

\section{KEYWORDS}

A small place; Jamaica

Kincaid; Antigua; tourist; host; literary tourism

\section{Introduction}

Nowadays we often hear voices of protest against tourism and a certain type of tourist revealing a discontentment that has frequently emerged in response to tourism saturation, from social movements at destinations where people see their lives negatively affected by tourism. This dissatisfaction towards tourism occasionally occurs in some of Jamaica Kincaid's texts, ${ }^{1}$ but it is A small place (1988a) that portrays Antigua as a tourist destination and tourism as a form of neo-colonialism. This text depicts the uneasy balance between the visited and the visitor, and what being a tourist and a host in Antigua means. In fact, apart from the essay 'The ugly tourist' (Kincaid, 1988b), first published in Harper's Magazine and months later as the opening chapter of $A$ small place, this is Kincaid's most vehement manifesto on the impacts of mass tourism on the lives of the Antiguans. Nevertheless, we must highlight that although this tension resembles what we now refer to as 'overtourism', ${ }^{2}$ in this work the underlying conflict between tourists and locals presents very particular contours grounded on the colonial history of Antigua. Thus, A small place is an excellent starting point not only to examine the tourist/host relationship and the impacts of mass tourism on a destination where tourists

CONTACT Rita Baleiro rbaleiro@ualg.pt, rita.baleiro@gmail.com E Languages Department, School of Management, Hospitality and Tourism, University of the Algarve, Campus da Penha, 8005-139 Faro, Portugal 
are served and locals are servers, but to offer strategies that could minimise these issues. Therefore, to address these problems as well as the urgently needed diversification of tourism in Antigua (and in the Caribbean countries in general), by placing an emphasis on cultural tourism (Jordan \& Jollife, 2013, p. 5; Tsikata, Moreira, \& Hamilton, 2009, pp. $x x x, 87,148)$, in this work we suggest developing literary tourism. Moreover, this type of tourism in the Caribbean has been scarce and limited to a few literary festivals (Weaver, 2001: 164) and authors' houses. Our paper has been carried out in the scope of both literature and tourism studies, and offers a cross disciplinary analysis and interpretation of Jamaica Kincaid's A small place (1988a), focusing on the author's point of view on tourism and tourists' behaviour in Antigua, as well as on the hosts' reaction to tourism and tourists and their impact on the local community and culture. Thus, we aim to promote interdisciplinary dialogue between literary and tourism studies, acknowledging the power of literature to mirror and think society, whilst confirming that in tourism terms there is definitely "life beyond the text"' (Robinson, 2004, p. 61).

Jamaica Kincaid is the pseudonym of Elaine Potter Richardson, born on 25th May 1949 in Antigua. At 17, she left her family, changed her name, and entered the United States. There she worked first as an au pair, then she collaborated for 20 years with the New Yorker magazine. She now lives in Vermont, where she works as a college professor teaching creative writing in California and Boston Universities (Bonetti, 1992, pp. 123-142).

Overall, this author's writing can be defined as objective ('motivated by everyday concerns, ones that have precise locations and specific contexts', Shima, 2004, p. 61), lucid and provocative, often containing a denouncing or outraged tone against the powers-that-be and against the oppression of the weak by the powerful, and of the colonised by the colonists. We should remember, on this subject, that Antigua was a British colony until 1981, just seven years before the release of $A$ small place.

In this intense, quasi-autobiographical, novelistic essay of just 80 pages (as in the Farrar, Strauss and Giroux edition, for instance), Kincaid depicts the tourism industry as having traces of colonial rule and 'adopts the deceptively simple style of a knowing child (Kipling's "half-devil and half-child") to interrogate those patterns which established the English as superior and the Antiguans as necessarily inferior' (Ashcroft, Griffiths, \& Tiffin, 2003, p. 85). By doing this, this literary text embodies a number of specific semantic effects (described next) that make it especially suitable for an interdisciplinary exegesis in literature and tourism studies. As such, our analysis suggests that Kincaid's text shares the distinctive attributes of those literary texts examined in this field of study, and that have been clustered under the classification of 'tourist literature' (a taxonomy by Harald Hendrix, 2014, pp. 19-29). This label refers to those texts whose authorship or representations of space may enrich and/or resignify space. In other words, tourist literature texts can produce literarily meaningful places that, in turn, have the effect of motivating the readers to metamorphose into tourists and travel beyond the text, in order to become closer to the book, to the author and the character(s) (Hendrix, 2014, p. 23). In this regard, these texts can foster literary tourism: a subset of cultural tourism, that refers to visits to places that are somehow connected to literature (Butler, 2000, p. 360). This type of niche tourism has risen over the last three decades, ${ }^{3}$ and has been of increasing interest to the academics. ${ }^{4}$

In this context, literature is used as a layer of creative production that can add to the (re)building of a place's profile (Carson, Hawkes, Gislason, \& Cantrell, 2016, p. 1). 
After examining several of these texts, however, we have found other texts that, in our view, can also be labelled as tourist literature, mainly because they can also be analysed in literature and tourism studies. We are talking about those literary texts that provoke a debate about tourism and its practices, above all, because the plot fosters an analysis and interpretation from that angle.

As such, Kincaid's A small place shares these two features of tourist literature: on the one hand, along with the author's biography, for example, it can (re)create space in order to recover and/or to (re)construct memories (Baleiro \& Quinteiro, 2014, p. 33), and promote a different reading of the physical geography of Antigua that in turn can foster the production of literary tourism experiences (e.g. literary itineraries). On the other hand, its narrative can motivate a theoretical analysis of the tourism phenomenon on the island (e.g. tourists, host and tourist relationship, responsibility, ethics and sustainability in tourism, the impact of the tourism industry, amongst other aspects). Our analysis and interpretation of $A$ small place suggest that we can take Kincaid's text (a very harsh text censuring the behaviour of western tourists in Antigua, and of Antigua's government) to consider promoting literary tourism experiences that could potentially attract a type of tourist who is antagonistic to the mass tourist (portrayed in Kincaid's 1988a text). Tourists who travel to get in touch with the local population, to visit sites other than the traditional tourist places and who are willing to spend more money on their holidays if they know that this money will bring some sort of benefits to the local communities (Fennell, 2008, p. 5).

Having said this, we have structured this article as follows: first, we analyse and interpret Kincaid's $A$ small place (bearing in mind that the text intertwines autobiographical and fictional narrative) to identify and comment on the author's view on tourism, tourists and hosts' reaction in Antigua, in 1988, at the time a paradigm of an idyllic and exotic tourist destination. Then, we will explore the possibility of taking Kincaid's text and biography as a resource for the development of literary tourism in Antigua.

\section{Tourism, tourists and hosts in A small place: a portrait of Antigua in 1988}

The narrative structure of $A$ small place is clearly divided in two different parts. The first consists of a fierce accusation of the damage caused by slavery and colonialism, and the second addresses the remorseless accusation of the post-colonial government's behaviour in perpetuating Antigua's neo-colonial status, by fomenting inequalities and maintaining an economic dependency on developed countries. In it, Kincaid describes governing entities as a new generation of slave traders, who stand for their own interests instead of protecting those of the population. By doing so, and according to Kincaid's narrator, the rulers have kept Antiguans in poverty whilst sustaining a privileged lifestyle, making a fortune with real estate, car dealerships, ${ }^{5}$ and, above all, tourism. The reference to the way the tourism industry has been operated in Antigua is the central thread linking both parts of this book and is presented here as the economic activity that transformed these people, 'the descendants of the slaves', into servants of the tourists (Alessandrini, 2014 , p. 558). Consequently, tourism shaped the country, and changed it from a colonial enclave into a tourist enclave, where a clear boundary between the tourist space and the inhabitants space stands out (Taylor, 2001, p. 16). In fact, in the twentieth century, the tourism industry took the place of the sugarcane industry as the primary source of 
income for Antigua's economy: 'In Antigua and Barbuda, tourism creates direct and indirect employment opportunities for approximately over $90 \%$ of its citizenry' (Wright, 2016, p. 122). Kincaid's text portrays an economy that is similar to other Caribbean countries, where the creation of giant infrastructures, namely for the tourism industry, implies a colossal national investment that ultimately means an extra effort for the taxpayers, huge environmental impact, and taking advantage of cheap labour force (Gmelch, 2003/2012, p. 9). An exploitation that endures in the twenty-first century, as denounced in the 21 testimonies of Barbados tourism staff collected by George Gmelch in Behind the smile: The working lives of Caribbean tourism (2003/2012). ${ }^{6}$ Although these testimonies were not collected in Antigua, they are nevertheless relevant to our work, as Barbados is close to Antigua not only geographically and historically, but also in the kind of inbound tourism markets and in their economic dependency on tourism.

In A small place, Kincaid depicts Antigua to an unenlightened tourist, through a narrator - a native tourist guide - and her words manage to create a very accurate array of effects, mainly because of their strength. And this is done in such a way that, like a stone cast in water causing a set of visible concentric ripples from the point where it fell, the words have resonance and create effects with several layers of significance. Thus, after reading this text, we understand that Kincaid: (i) discloses that Antigua has become a mix of a tourist destination, ex-colony and neo-colonialist territory (McLeod, 2008, p. 77); (ii) shows that in Antigua, the impact of the complex relationships between colonised and colonist, Westerners and non-Westerners, and also between white and black people did not disappear with the end of the colonial period; (iii) creates a narrative that 'literally and symbolically' gives a voice and the right to reply to those who have been colonised for nearly three hundred and fifty years (Osagie \& Buzinde, 2011, p. 213); (iv) offers foreign readers a new insight into tourism in Antigua, revealing the island's true colours, its inhabitants, their way of life and the impact of tourism on them.

We understand that the narrator's intention is not to offer a pleasurable reading experience to the narratee/tourist, whom he/she addresses in the first sentence of the text ('If you go to Antigua as a tourist, this is what you will see', Kincaid, 1988a, p. 3), but to show the tangible adverse impact of European colonisation, as well as that of the tourism industry in Antigua (Pedwell, 2013, p. 20). For that reason, the narrator/tourist guide compels the clueless visitor to go on an unordinary and unexpected tour of the island so he/she can witness what lies behind the enactment of deception and commonplaceness of this type of tourist destination (Cohen, 1988, p. 377). A (small) place where coconut trees, swaying palm trees, fine sand beaches and the blue sea enable the visitors 'to satisfy a number of motives including novelty, escape, relaxation, comfort, well-being, and so on, in achieving self-realization (Gnoth, 1997), with a broad spectrum of offerings geared towards the satisfaction of these needs' (Fennell, 2008, p. 3).

In a second person address, Kincaid's narrator/tour guide neglects to show the glamour of tourist distractions, and forces the narratee/tourist to visit Antigua deprived of any veils or masks, and to acknowledge the real impact of centuries of colonisation, enslavement and government-fuelled poverty. ${ }^{7}$ By constraining the tourist's view, the narrator subverts any expectations the regular tourist to this type of destination might have, considering that the tourist attractions, the landmarks and the places of interest are, in this case, Antigua's problems, vices, and the marks left by British colonisation. Kincaid's narrator/tourist guide protests vigorously against the destructive cultural impacts imposed on the 
Antiguans by the western world, in the past as well in the present, that have immensely contributed to annihilate the African-based culture of those born in Antigua (Lan, 2009, p. 6). In other words, the narrator refuses to abide by the usual tourist's gaze, and for that reason creates this unexpected and disturbing tour of the scars left by the subjugation of the Antiguans, in an effort to balance the conflicting power relationship between hosts and tourists. A hard to achieve balance, considering that in most interactions between Westerners and non-Westerners, colonialism has been, and remains, one of the most compelling influences (Ashcroft et al., 2003). Taking into account that tourism is probably one of the best examples of cross-cultural interaction, by addressing the British (and by extension contemporary western tourists), Kincaid's narrator identifies tourism as an additional instance of colonialism that Antigua cannot avoid due to its economy subordinate to tourism. Sinclair-Maragh and Gursoy (2015) corroborate this insight. After analysing a number of studies on the subject, they have concluded that tourism is indeed a form of imperialism, mainly because it promotes investments by international organisations in developing countries to facilitate development which, in turn, results in a power dominance relationship between the rich and poor nations (Sinclair-Maragh \& Gursoy, 2015, p. 144). This can explain why Kincaid portrays tourists as neo-colonialists, just as Justin D. Edwards points out when he states that:

The book speaks directly to the American and European tourists who journey to Antigua in search of the escapism offered by sun, sand, and the Caribbean Sea. For Kincaid, these travellers perpetuate the slavery and imperialism practiced by their forefathers - not by keeping blacks in bondage chains but by contributing to an economy that keeps Antiguans shackled to tourism Kincaid thus sees the citizens of Antigua, formerly British subjects, as still caught up in hierarchies of colonization and economic imperialism. (Edwards, 2007, p. 77)

Therefore, Kincaid's narrator maintains that tourists to the Caribbean (as the colonisers before them) often overlook the identity of the place, aloof to the pernicious impact of their presence and of tourism industry (e.g. increased pollution levels, destruction of vulnerable ecosystems and the undermining of local culture, see Carrigan, 2010, p. 154). As an expression of the indifferent individuality of the tourist, Kincaid's narrator voices in a mix of narration and free indirect speech, the disturbing fact that they can feel 'alive and inspired at the sight' of 'heaps of death and ruin' (Kincaid, 1988a, p. 16). But even though Kincaid's narrator despises tourists, assigning them epithets like 'ugly', 'empty thing', 'stupid thing', 'piece of rubbish' that pauses 'here and there to gaze at this and taste that' (Kincaid, 1988a, p. 17), the narrator acknowledges that all human beings - 'every native of every place' have the need to escape 'the banality' of life (Kincaid, 1988a, p. 18), although only the richest can afford that:

That the native does not like the tourist is not hard to explain. For every native of every place is a potential tourist, and every tourist is a native of somewhere. Every native everywhere lives a life of overwhelming and crushing banality and boredom and desperation and depression, and every deed, good and bad, is an attempt to forget this. Every native would like to find a way out, every native would like a tour. But some native - most natives in the world cannot go anywhere. They are too poor. They are too poor to go anywhere. (Kincaid, 1988a, pp.18-19)

One of the most vehement criticisms of the tourism phenomenon as it stood in Antigua in the 1980s stated by Kincaid's narrator has to do with culture; with the way this form 
of neo-colonialist type of tourism inhibits the consolidation of a true Antiguan culture. A culture that stems from fragments of African roots and European heritage, and results in a hybrid and complex identity (a consequence of almost four centuries of enslavement and subordination that helped erase the African heritage) that negatively interferes with a clear recognition of an Antiguan cultural identity from those visiting the island (Edwards, 2007, pp. 6-7, 10).

In $A$ small place, the criticism against this cultural debility is strong, acknowledging that it derives, primarily, from the path defined by the dominion of the owner (and proprietary culture) over the slave that has contributed to the inexistence of a solid, stable and well defined cultural legacy and identity to return to after independence in the 1980s. In this work, the narrator denounces a set of colonialist impositions that 'disempowered the subject population by denying it any extracolonial identity', impositions that 'worked to eradicate pre-colonial memories of self, history and place' (Thieme, 2016, p. 44). This is a frequent criticism in Kincaid's work, and it is also present in texts such as 'What Joseph Banks wrought' (1999) and My garden (1999), in which the reader is made aware that in Antigua, even the majority of the flora is not native. It was brought by the British. Furthermore, the species that already existed on the island were (re)named by them, using their language: 'these new plants from far away, like the people far away, had no history, no names, and so they could be given names' (Kincaid, My garden, p. 91; quoted in Thieme, 2016, p. 44).

On the same line of thought, the narrator/tourist guide in A small place rejects vigorously the models imposed by the consecutive colonisers (assimilated and legitimised by the current governments) and pleads for the recovery or, should we say, the establishment of an Antiguan culture. These are the reasons why, during this journey through the island, the natives of Antigua are compared to orphans who were denied the African motherland, and who were also stripped of their gods and the language in which they communicate: '[...] what I see is millions of people, of whom I am just one, made orphans: no motherland, no fatherland, no gods, no mounds of earth for holy ground [...]' (Kincaid, 1988a, p. 31). Not having their own language to communicate is the greatest void, because it forces the Antiguans to use the language of the coloniser to denounce the theft of their cultural identity, and in the English language there are no words to express 'the horror of the deed, the injustice of the deed, the agony, the humiliation inflicted on me' (Kincaid, 1988a, p. 32).

Another meaningful example of this hesitant culture - the expression of the colonisers' power - is pointed out when the narrator ironically remarks that in Antigua the day of independence from British rule is celebrated, not with a local tradition, but by going to church and thanking God, a British God (Kincaid, 1988a, p. 9). The ongoing subordination inflicted on the people of Antigua (first by the slave owners, then the colonisers and later by tourism) has not amounted to financial autonomy, a reward that could have counterbalanced powers. On the contrary, the country was kept poor, the landscapes were standardised (comprised of an excessive and uniformed sequence of 'illustrated postcards', with the same palm trees, pools, hotels), and traces of cultural identity were erased (Brohman, 1996, pp. 48-70).

In $A$ small place, we read that the colonial library of Antigua has displayed a 'repairs are pending' sign (1988a, p. 9) for more than a decade. According to Edwards (2007, p. 102), whose interpretation we subscribe to, this stands as a metaphor for the Antiguan postcolonial culture that, although free from European rule, is not stable or sturdy enough 
to be the structure for an indigenous identity, able to keep up with the acquired political independence (in 1981). In this regard, when Kincaid published A small place in 1988, there was a pressing need to consolidate a genuine Antiguan culture, to make Antiguans (re)embrace their cultural legacy and to make it visible to the eyes of those who visit the island. As a consequence, in A small place, (mass) tourism is portrayed as the main obstacle to this process, for it perpetuates the submission and uncertainty of Antigua's culture. Just as Weeden (2002) argues, tourism is without a doubt 'able to bring economic benefit, but it can also reinforce social and economic disadvantages of the host population, especially within developing countries' (p. 141). Which means that in countries like Antigua, tourism is the industry that feeds the people, and for that reason is fundamental to their survival. As such, the key to this dilemma could be to foster types of tourism based on the economy of experiences (Pine \& Gilmore, 1998, pp. 97-101) that, along with mass tourism, whilst relieving its pressure, would contribute to the empowering of the Antiguan heritage and its people, and at the same time meeting the expectations and needs of a new type of tourist.

\section{A small place, the author and the island: literary tourism experiences}

Almost 30 years have passed since $A$ small place's first edition, and it is now acknowledged (e.g. Harrison \& Sharpley, 2017) that mass tourism is and probably will be the norm, mainly because: 'capitalism and international tourism are likely to continue into the foreseeable future, [and] virtually all forms of "alternative" tourism will remain linked to and dependent on mass tourism, and none of them will replace it' (Harrison \& Sharpley, 2017, p. 6). Although some authors (MacLeod, Hayes, \& Slater, 2009, p. 156) argue that there has been 'a decline of mass tourism', we subscribe to the more consensual view that a different type of tourist has emerged over the last decade. A type of tourist that is distinct from the one depicted in Kincaid's narrative, above all because tourists are now more sophisticated consumers, who seek authentic experiences and place an emphasis on a relational experience with the local community. They enjoy experiencing the local products, and the local 'atmosphere' (i.e. the 'local', the 'everyday' and their 'edgy' features) (Richards, 2017, pp. 173-174). These tourists are aware of the importance of their choices and attitudes, and for them ethical issues matter and influence their behaviour as consumers. In this regard, Weeden (2002, p. 142) notes that when this type of consumer perceives 'little difference between competing products or brands, ethics and ethical products can be an opportunity for differentiation". 8

An example of ethical tourism experiences can be seen in the context of literary tourism, in the sense that they promote sustainable use of the environment, they involve local communities, as 'locals become the providers of tourist experiences', by interpreting 'the places they live in for the tourist' (Richards, 2017, p. 173). Although, in 'sharing the new localities of tourism' (2017), Greg Richards is not referring specifically to literary tourism, his assumptions do especially fit to literary tourism experiences. In fact, Richards examines the question of a collaborative (or sharing) economy in the tourism sector, a model based on horizontal networks and the participation of a community which is clearly the case of most literary tourism practices.

In a chapter on the development of sustainable products for Caribbean tourism, Wright formulates a set of proposals, amongst which we have highlighted the following: 
'Fomenting the development of tourism sub-sectors of special interest, such as agrotourism, local tourism, health tourism, ecotourism and sport and cultural tourism, to expand the product's scope.' (2016, p. 132). Wright puts forward, amongst others, the development of cultural tourism, and it is within this niche that we believe it would be positive to develop literary tourism products and to stage literary tourism experiences in Antigua. These could be unique and memorable experiences, 'inherently personal, existing only in the mind of an individual who has been engaged on an emotional, physical, intellectual, or even spiritual level' (Pine \& Gilmore, 1998, pp. 98-99). Experiences that are built on the connection between the physical geography of the island (as space) and Jamaica Kincaid's life history and most famous literary workscan potentially be attractive to a new type of tourists, who are the opposite of those addressed by Kincaid in A small place. In fact, literary texts can add new layers of meaning to the space they represent and/or they have a connection to. Therefore, there is a huge potential in establishing those connections and references in $A$ small place's narrative, Antigua's physical geography, and Kincaid's biographical facts. As Robinson and Andersen assert,'literary tourism is both supply-led (what is available, which literary homes are available for preservation) and demand-led (what actually interests the literary tourist)' (2004, p. 28), which means that Kincaid's work and biography can generate a large and diverse number of literary places (those available and those to be created and/or marked in the physical map of Antigua). Besides, it can promote several literary tourism products and experiences, amongst others:

- An itinerary following the route mapped by the narrator (that could be complemented by landmarks from the colonial past, e.g. sugarcane plantations, the Botanical Garden, public buildings, etc.);

- Tours to Kincaid's places on the island: where she was born, where she lived (St. John's, Nelson Street), the school she attended (Princess Margaret School), the library she went to (the building of the old library), the places where she got her inspiration from, etc.;

- A Jamaica Kincaid literary café/hostel/hotel, where seminars, conferences and literary dinners could take place;

- A literary festival.

It is our belief that literary tourism could make an important contribution to rebranding the image of Antigua as a tourist destination which provides an alternative to sun, sea, sand and palm trees. First of all, because implementing literary tourism experiences would contribute to the promotion of the island's cultural heritage (sites, history, ways of life, buildings, art, etc.). Secondly, because 'the development of special interest activities [...] and the targeting of niche tourist segments can significantly improve the costs inflicted by seasonal tourism demands' (Farmaki, Altinay, \& Yaşarata, 2016, p. 37), reducing unemployment during low season and hence poverty, which is the case in a sun and sea destination such as Antigua. Finally, because literary tourism is a type of small-scale tourism that happens mostly in places (physical and social) that are not traditionally intended for tourists. Therefore, it promotes a closer tourist/host relation, and thus mutual awareness and respect. Besides, as literary tourism is not intended for the masses (with very few exceptions), ${ }^{9}$ it may not be very appealing to the tourism industry, and it may be developed by the local community, empowering and benefiting local residents. In fact, literary tourism creates opportunities to diversify the local economy and 
provide equitable income and other economic benefits, which comply with the definition of community-based tourism, an 'effective tool for achieving economic and social development, particularly in rural and underdeveloped areas where options for alternative economic development are constrained by geographical and economic factors' (TuanAnh, Weaver, \& Lawton, 2016, pp. 161-162), as is the case in Antigua.

The creation and staging of literary tourism experiences should be necessarily structured and organised by specialists or specialist organisations and thus relies on the official entities for the recovery of buildings, sign placement and promotion. The 'interaction and communication with relevant 'outside' stakeholders (e.g. investors, developers, planners and managers from the outside community)' (Tuan-Anh et al., 2016, p. 162) is also important, however, its maintenance and promotion relies greatly on the involvement of the community (citizens, local education institutions, local cultural associations); on them assuming the role of key stakeholders. For these products/experiences to succeed, to survive and for residents to derive maximum benefits from tourism, there has to be a high level of self-mobilisation. The local community must be motivated to participate in it by taking initiatives of their own, without being driven by outside institutions. Antiguans would benefit directly from the presence of tourists in the island if they led the tours, promoted workshops about local activities and products, created micro-companies to market literary souvenirs, ${ }^{10}$ and articulated these new offers with other types of cultural tourism (heritage and food tourism, for instance) and forms of tourism (such as ecotourism, nature tourism and agrorural tourism). Moreover, most products and experiences designed for literary tourism (literary itineraries, literary museums, literary parks, literary festivals, amongst others ...) promote a closer tourist/host interaction as already mentioned, and therefore make a useful contribution to mitigating tensions such as the ones exposed in Kincaid's book.

Most literary tourism experiences foster encounters, and therefore contribute to the dissolving of barriers that usually separate tourists and locals. But, above all, literary tourism experiences and products can have a strong educational potential for the local community, ${ }^{11}$ contributing to the increasing of 'income and education while concurrently preserving traditional culture and protecting the natural environment' (Tuan-Anh et al., 2016, p. 177), and so in the case of Antigua, contributing to the establishment of the identity longed by Jamaica Kincaid's narrator.

\section{Conclusion}

Kincaid's 1988a text raises many issues about tourism in Antigua: tourism as an expression of neo-colonialism, racism, the poverty of the locals vs. the ostentation and privilege of tourists, the indetermination of the local culture, acculturation, and seasonality. A set of questions that, almost 30 years later, are still current in most (poor) tourist destinations (Wright, 2016, p. 122): cultural and physical gaps that separate the tourist space and the host space as well as the tourists and the local community, the unequal distribution of tourism industry profits, the challenges in intercultural communication and the (un)sustainability of mass tourism. In fact, in the case of Antigua, the issues highlighted by Kincaid's narrator correspond to many of those listed by Sharpley $(2001$, p. 65) as being characteristic of the economies of islands that are simultaneously microstates: small geographical size, distance and isolation from metropolitan centres, a limited economic base, a lack of resources, strong dependency on the tourism sector; a development based on a 
centre - periphery dependency mode. Farmaki et al. also add seasonal unemployment to the list (2016, p. 37).

Considering this set of issues, and understanding that Antigua cannot dispense mass tourism, which guarantees the livelihood of more than $90 \%$ of the population, or escape the remaining constraints of an island/microstate/ex-colony, we have highlighted the opportunity to create literary tourism products and experiences inspired by the life and works of Jamaica Kincaid as a complementary offer to mass tourism that so far has been neglected. We believe that literary tourism could meet the needs of many twentyfirst century tourists who wish for a more responsible, sustainable and ethical tourism experience. Besides, it could have an effect of bringing tourists and hosts closer, as well as educating the locals about their history and culture. Considering the examples of other former colonies that are now tourist destinations where there is an offer of literary tourism products/experiences (such as Haiti with its Literary Festival and literary tours; Cartagena de las Indias and Gabriel García Marquez's tours and literary cafés; Cuba and its literary tours on local authors and on Hemingway; Jamaica and its Calabash Literary Festival; Malta with its Mediterranean Book Festival), we believe that literary tourism in Antigua could bring about an increase in responsible and more sustainable tourism practices.

$(\mathrm{Re})$ creating the island of Antigua as a literary space could contribute to reducing the amount of negative impact of the tourism industry on the island, as well as helping to develop a closer relationship between tourists and hosts. These changes would potentially modify the perspective that Antiguans and visitors have of each other. Hence, Kincaid's opening sentence - 'If you go to Antigua as a tourist, this is what you will see' - could be rewritten 'If you go to Antigua as a tourist, this is what you will experience.'

\section{Notes}

1. Namely in Kincaid's Annie John (1985), where tourists are referred to as new settlers and in Among flowers: A walk in the Himalayas (2005), where the author portrays herself as a tourist (Lang-Peralta, 2006, p. 42; Ewert, 2006, p. 118).

2. A concept coined by Rafat Ali (the CEO of Skift) in an August 2016 foreword to an article about the impacts of tourism in Iceland, entitled 'Foreword: the coming perils of overtourism' (https://skift.com/lceland-tourism).

3. Although there is no statistical data that clearly illustrates the increase of literary tourism in recent years, there are clear signs of its progressive expansion: the publication of numerous literary guides, an increase of merchandise with literary associations (Robinson, 2004, p. 65), the progressive interest of the media, the increasing number of film-induced literary tours, of literary parks, literary festivals and specialised travel agencies.

4. See Literature and tourism (Robinson \& Andersen, 2002), 'Going on (literary) pilgrimage: Constructing literary trails with particular reference to KwaZulu-Natal' (Stiebel, 2007), The literary tourist: Readers and places in Romantic and Victorian Britain (Watson, 2006), Literary tourism and nineteenth-century culture (Watson, 2009), Literatura y turismo (Argüelles-Meres et al., 2011) Turismo literario [Literary tourism] (Magadán Díaz \& Rivas García, 2011), El libro como atractor turístico [the book as tourism attractor] (Magadán Díaz \& Rivas García, 2013), Lit\&Tour: Ensaios sobre literatura e turismo [Essays on literature and tourism] (Quinteiro \& Baleiro, 2014), Researching literary tourism (Mansfield, 2015), Literatura e turismo: Turistas, viajantes e lugares literários [Literature and tourism: Tourists, travellers and literary places] (Quinteiro, Baleiro \& Santos, 2016) e Literatura e turismo: Viagens, relatos e itinerários [Literature and tourism: Travels, travel accounts and itineraries] (Baleiro, Quinteiro \& Santos, 2016).

5. See Kincaid (1988a, pp. 6-7). 
6. Gmelch's book aims to minimise the 'lack of local voice', and the focus of the book is the tourist/host encounter, the asymmetries that separate them, and the still indifferent, racist and colonialist attitude of tourists (Gmelch, 2003/2012, pp. x, 27-41).

7. Almost 30 years past the publication of $A$ small place, at present, poverty is still very much a reality. In fact, despite the increase 'in arrivals, employment and revenue', there has not been improvements in the living standards of average Caribbean citizens, since 'approximately $36 \%$ of Latin America and the Caribbean's population live below the poverty line, the same percentage as a decade ago." (Wright, 2016, p. 119).

8. Ethical products are often associated with tourists' belief that their presence translates into results that promote: (i) Community satisfaction with tourism, (ii) Economic benefits of tourism, (ii) Water availability and conservation, (iii) Sewage treatment - wastewater management, (iv) Solid waste management, (v) Development control (Wright, 2016, p. 121).

9. Namely those connected with J.K. Rowling's Harry Potter and with Dan Brown's Da Vinci Code and some large literary festivals and fairs, such as the Jaipur Literature Festival $(800,000$ visitors) and the Miami Book Fair (250,000 visitors).

10. In Cordisburgo, Brazil, for example, local people embroider and sell images inspired by the narratives of Guimarães Rosa.

11. See Baleiro \& Quinteiro (2017, pp. 20-23).

\section{Disclosure statement}

No potential conflict of interest was reported by the authors.

\section{Notes on contributors}

Rita Baleiro holds a PhD and a Masters in English and Portuguese Studies from the New University of Lisbon, and a First Degree in Modern Languages and Literatures - Portuguese and English - also from the New University of Lisbon. She is a senior lecturer of English for Specific Purposes, and Portuguese Language and Culture at the School of Management, Hospitality and Tourism of the University of the Algarve. She is a full member of the Research Centre for Comparative Studies (CEC), based at the Faculty of Arts and Humanities at the University of Lisbon, where she co-coordinates the Lit\&Tour project. She collaborates with the Tourism, Space and Urbanities Research Group of the Federal University of Rio de Janeiro, and with CITUR (Center for Research, Development and Innovation in Tourism). She is also a member of the project Atlas of the literary landscapes in continental Portugal. She has been co-chief-editor of Dos Algarves: A Multidisciplinary e-Journal since 2007. Her research interests include literature studies, and the intersections between literature and tourism. She has authored and co-authored several national and international scientific publications.

Silvia Quinteiro is a coordinating professor at the University of the Algarve - School of Management, Hospitality and Tourism. She holds a First Degree in Modern Languages and Literatures (Portuguese and German Studies) from the New University of Lisbon, and a Masters and PhD in Comparative Literature from the University of Lisbon. She is a full member of the Research Centre for Comparative Studies (CEC), based at the Faculty of Arts and Humanities at the University of Lisbon, where she created and now co-coordinates the Lit\&Tour project. She collaborates with the Tourism, Space and Urbanities Research Group of the Federal University of Rio de Janeiro and with CITUR (Center for Research, Development and Innovation in Tourism). Her research interests include comparative literature, and the relation between literature and tourism. She has authored and co-authored several national and international scientific publications.

\section{ORCID}

Rita Baleiro (iD) http://orcid.org/0000-0002-3188-5150

Sílvia Quinteiro (D) http://orcid.org/0000-0003-1809-7341 


\section{References}

Alessandrini, A. C. (2014). Small places, then and now: Frantz fanon, Jamaica kincaid, and the features of postcolonial criticism. Journal of Postcolonial Writing, 46(5), 553-564. doi:10.1080/17449855. 2010.507926

Ali, R. (2016, 23 August). Exploring the perils of overtourism [foreword]. Retrieved from https://skift. com/2016/08/23/exploring-the-coming-perils-of-overtourism/

Argüelles-Meres, L. A., Herrero Montoto, M., Magadán Díaz, M., Murias Ibias, A., Rivas García, J., \& Valle Cobreros, A. (2011). Literatura y turismo. Oviedo: Septem Editores.

Ashcroft, B., Griffiths, G., \& Tiffin, H. (2003). The post-colonial studies reader. London: Routledge.

Baleiro, R., \& Quinteiro, S. (2014). Da cartografia do Danúbio à construção de um itinerário turístico: Uma leitura de Danúbio de Claudio Magris [From the cartography of Danube to the creation of a literary itinerary: A Reading of Danube, by Claudio Magris]. In S. Quinteiro, \& R. Baleiro (Eds.), Lit \& Tour: Ensaios sobre literatura e turismo [Lit\&Tour: Essays on literature and tourism] (pp. 31-44). Vila Nova de Famalicão: Edições Húmus.

Baleiro, R., \& Quinteiro, S. (2017). Construção de um passeio literário: Cândido Guerreiro e a aldeia de Alte [Creating a literary walk: Cândido Guerreiro and the village of Alte]. Loulé: Câmara Municipal de Loulé.

Baleiro, R., Quinteiro, S., \& Santos, I. D. (Eds.). (2016). Literatura e turismo: Viagens, relatos e itinerários. Faro: Universidade do Algarve.

Bonetti, K. (1992). An interview with Jamaica kincaid. The Missouri Review, 15(2), 123-142.

Brohman, J. (1996). New directions in tourism for third world development. Annals of Tourism Research, 23(1), 48-70.

Butler, R. (2000). Literary tourism. In J. Jafari (Ed.), Encyclopedia of tourism (p. 360). London: Routledge.

Carrigan, A. (2010). Postcolonial tourism, island specificity, and literary representation: Observations on Derek Walcott's Omeros. Space and Culture, 13(2), 154-163.

Carson, S., Hawkes, L., Gislason, K., \& Cantrell, K. (2016). Literature, tourism and the city: Writing and cultural change. Journal of Tourism and Cultural Change, 14(4), 1-13. doi:10.1080/14766825.2016.1165237

Cohen, E. (1988). Authenticity and commoditization in tourism. Annals of Tourism Research, 15, 371386. doi:10.1016/0160-7383(88)90028-X

Edwards, J. (2007). Understanding Jamaica kincaid. Columbia, DC: South Carolina Press.

Ewert, J. (2006). Jamaica Kincaid's ambivalent garden book. In L. Lang-Peralta (Ed.), Jamaica Kincaid and Caribbean double crossings (pp. 113-126). Newark, NJ: University of Delaware Press.

Farmaki, A., Altinay, L., \& Yaşarata, M. (2016). Rhetoric versus the realities of sustainable tourism: The case of Cyprus. In P. Modica \& M. Uysal (Eds.), Sustainable island tourism: Competitiveness, and quality-of-life (pp. 35-50). Boston, MA: CABI.

Fennell, D. (2008). Responsible tourism: A kierkegaardian interpretation. Tourism Recreation Research, 33(1), 3-12. doi:10.1080/02508281.2008.11081285

Gmelch, G. (2003/2012). Behind the smile: The working lives of Caribbean tourism. Bloomington, IN: Indiana University Press.

Harrison, D., \& Sharpley, R. (2017). Introduction. In D. Harrison \& R. Sharpley (Eds.), Mass tourism in a small world (pp. 1-14). New York, NY: CABI.

Hendrix, H. (2014). Literature and tourism: Explorations, reflections and challenges. In S. Quinteiro \& R. Baleiro (Orgs.), Lit\&Tour: Ensaios sobre literatura e turismo [Lit\&Tour: Essays on literature and tourism] (pp. 19-29). Vila Nova de Famalicão: Húmus.

Jordan, L.-A. \& Jollife, L. (2013). Heritage tourism in the Caribbean: Current themes and challenges [editorial]. Journal of Heritage Tourism 8(1), 1-8. doi:10.1080/1743873X.2013.765735

Kincaid, J. (1988a). A small place. New York, NY: Farrar, Straus and Giroux.

Kincaid, J. (1988b, September). The ugly tourist. Harper's Magazine. Retrieved from https://harpers. org/archive/1988/09/the-ugly-tourist/

Lan, P.N. (2009). The carnivalesque and cultural dialogues in Jamaica Kincaid's writings. Master's thesis. Singapore: National University of Singapore.

Lang-Peralta, L. (2006). Ambivalence in Jamaica Kincaid's Lucy and My Garden book. In L. Lang-Peralta (Ed.), Jamaica Kincaid and Caribbean double crossings (pp. 33-44). Newark, NJ: University of Delaware Press. 
MacLeod, N., Hayes, D., \& Slater, A. (2009). Reading the landscape: The development of a typology of literary trails that incorporate an experiential design perspective. Journal of Hospitality Marketing \& Management, 18(2-3), 154-172. doi:10.1080/19368620802590183

Magadán Díaz, M., \& Rivas García, J. (2011). Turismo literario. Oviedo: Septem Editores.

Magadán Díaz, M., \& Rivas García, J. (2013). El libro como atractor turístico. Oviedo: Septem Editores. Mansfield, C. (2015). Researching literary tourism. Plymouth: Shadows Books \& Media.

McLeod, C. (2008). Constructing a nation: Jamaica Kincaid's A small place. Small Axe, 25, 77-92. doi:10. 2979/SAX.2008.-.25.77

Osagie, I., \& Buzinde, C. N. (2011). Culture and postcolonial resistance: Antigua in Kincaid's A small place. Annals of Tourism Research, 38(1), 210-230. doi:10.1016/j.annals.2010.08.004

Pedwell, C. (2013). Affect at the margins: Alternative empathies in A small place. Emotion, Space and Society, 8, 18-26. doi:10.1016/j.emospa.2012.07.001

Pine, B. J., \& Gilmore, J. H. (1998). Welcome to the experience economy. Harvard Business Review, 76 (4), 97-105.

Quinteiro, S., \& Baleiro, R. (Orgs.). (2014). Lit \& Tour: Ensaios sobre literatura e turismo. Vila Nova de Famalicão: Edições Húmus.

Quinteiro, S., Baleiro, R., \& Santos, I. D. (Eds.). (2016). Literatura e turismo: Turistas, viajantes e lugares literários. Faro: Universidade do Algarve.

Richards, G. (2017). Sharing the new localities of tourism. In D. Dredge \& S. Gyimóthy (Eds.), Collaborative economy and tourism: Perspectives, politics, policies and prospects (pp. 169-184). New York, NY: Springer.

Robinson, M. (2004). Between and beyond the pages: Literature-tourism relationships. In M. Robinson \& H.-C. Andersen (Eds.), Literature and tourism (pp. 39-79). London: Thomson.

Robinson, M., \& Andersen, H.-C. (Eds.). (2002). Literature and tourism: Reading and writing tourism texts. London: Continuum.

Robinson, M. \& Andersen, H.-C. (2004). Reading between the lines: Literature and the creation of touristic spaces. In M. Robinson \& H.-C. Andersen (Eds.), Literature and tourism (pp. 1-38). London: Thomson.

Sharpley, R. (2001). Tourism in Cyprus: Challenges and opportunities. Tourism Geographies, 3(1), 64-86. DOI: 10.1080/14616680010008711

Shima, A. (2004). No beginning, no end: The legacy of absence in Jamaica Kincaid's. The autobiography of my mother. Kunapipi: Journal of Postcolonial Writing and Culture, 26(2), 61-73.

Sinclair-Maragh, G., \& Gursoy, D. (2015). Perceptions of imperialism and tourism: The case of developing island countries. Annals of Tourism Research, 50, 143-158. doi:10.1016/j.annals.2014.12.001

Stiebel, L. (2007). Going on (literary) pilgrimage: constructing literary trails with particular reference to KwaZulu-Natal. Scrutiny, 12(1), 93-106.

Taylor, J. (2001). Authenticity and sincerity in tourism. Annals of Tourism Research, 28(1), 7-26. doi:10. 1016/S0160-7383(00)00004-9

Thieme, J. (2016). Postcolonial literary geographies: Out of place. London: Macmillan.

Tsikata, Y., Moreira, E. P., \& Hamilton, P. C. (2009). Accelerating trade and integration in the Caribbean policy options for sustained growth, job creation, and poverty reduction. Washington, DC: The International Bank for Reconstruction and Development/The World Bank.

Tuan-Anh, L., Weaver, D., \& Lawton, L. (2016). Community-based tourism and development in the periphery/semi-periphery interface: A case study from viet Nam. In S. McCool \& K. Bosak (Eds.), Reframing sustainable tourism 2 (pp. 161-162). Dordrecht: Springer.

Watson, N. (2006). The literary tourist: Readers and places in Romantic and Victorian Britain. Basingstoke: Palgrave Macmillan.

Watson, N. (Ed.). (2009). Literary tourism and nineteenth-century culture. Basingstoke: Palgrave Macmillan.

Weaver, D. B. (2001). Mass tourism and alternative tourism in the Caribbean. In D. Harrison (Ed.), Tourism and the less developed world: Issues and case studies (pp. 161-174). Boston, MA: CABI.

Weeden, C. (2002). Ethical tourism: An opportunity for competitive advantage. Journal of Vacation Marketing, 8(2), 141-153.

Wright, A. (2016). Developing a sustainable Caribbean tourism product. In P. Modica \& M. Uysal (Eds.), Sustainable island tourism: Competitiveness, and quality-of-life (pp. 119-134). Boston, MA: CABI. 